Article

\title{
Fabrication of $\mathrm{CH}_{3} \mathrm{NH}_{3} \mathrm{PbI}_{3} / \mathrm{PVP}$ Composite Fibers via Electrospinning and Deposition
}

\author{
Li-Min Chao ${ }^{1, \dagger}$, Ting-Yu Tai ${ }^{1, \dagger}$, Yueh-Ying Chen ${ }^{1, \dagger}$, Pei-Ying Lin ${ }^{2, \dagger}$ and Yaw-Shyan Fu ${ }^{1, *}$ \\ ${ }^{1}$ Department of Greenergy, National University of Tainan, Tainan 70005, Taiwan; \\ E-Mails: liminchao@gmail.com (L.-M.C.); mucy6331@gmail.com (T.-Y.T.); \\ felicidad@livemail.tw (Y.-Y.C.) \\ 2 Department of Photonics, National Cheng Kung University, Tainan 70005, Taiwan; \\ E-Mail: sherry80128@gmail.com \\ $\dagger$ These authors contributed equally to this work. \\ * Author to whom correspondence should be addressed; E-Mail: ysfu@mail.nutn.edu.tw; \\ Tel.: +886-6-260-5031; Fax: +886-6-260-2205.
}

Academic Editor: Teen-Hang Meen

Received: 10 June 2015 / Accepted: 14 August 2015 / Published: 21 August 2015

\begin{abstract}
In our study, one-dimensional $\mathrm{PbI}_{2}$ /polyvinylpyrrolidone (PVP) composition fibers have been prepared by using $\mathrm{PbI}_{2}$ and $\mathrm{PVP}$ as precursors dissolved in $\mathrm{N}, \mathrm{N}$-dimethylformamide via a electrospinning process. Dipping the fibers into $\mathrm{CH}_{3} \mathrm{NH}_{3} \mathrm{I}$ solution changed its color, indicating the formation of $\mathrm{CH}_{3} \mathrm{NH}_{3} \mathrm{PbI}_{3}$, to obtain $\mathrm{CH}_{3} \mathrm{NH}_{3} \mathrm{PbI}_{3} / \mathrm{PVP}$ composite fibers. The structure, morphology and composition of the all as-prepared fibers were characterized by using X-ray diffraction and scanning electron microscopy.
\end{abstract}

Keywords: polyvinylpyrrolidone; perovskite; electrospinning

\section{Introduction}

Electrospinning is a novel and simple synthesis method for one-dimensional nanostructures. It stretches the solution using electrostatic forces and further spins it into a solid state. The fiber formed by electrospinning can achieve nano fineness and nanostructure surfaces. Thus, it can have different reactions with substances compared with macro materials [1]. One-dimensional nanofibers can promote 
charge transfer and reduce the recombination of the hole-electron pairs better than nanoparticles [2]. Basically, nearly all soluble or fusible polymers can be processed into fibers by electrospinning, provided that the molecular parameters and the process parameters are correctly adjusted [3]. Hereinto, polyvinylpyrrolidone (PVP) is a polymer containing lactam rings by which the polymer/metal-ion complexes can be formed. It is an important synthetic polymer with good complexation and adhesion properties, excellent physiological compatibility, low chemical toxicity, and reasonable solubility in water and most organic solvents, such as DMF, ethanol, and dichloromethane [4]. A lot of papers have reported the fabrication of electrospun composite fibers of PVP and metal compounds. Metal compounds are normally used in the form of sol-gel precursors, and the PVP fibers are used as templates to load the inorganic precursors [3]. Thereby, PVP was used for our study.

Lead iodide $\left(\mathrm{PbI}_{2}\right)$ is a high anisotropic semiconductor. It crystallizes in the $\mathrm{CdI}_{2}$ type of layer structure, composed of a hexagonal close packing of iodine ions with the small lead ions intercalated between alternate layers of iodine [5]. It is an intrinsic wide band gap semiconductor, and so has potential applications such as in room temperature photocells, X-ray imaging, gamma-ray detectors, and photovoltaic [6]. A number of research works have been reported on the synthesis of the $\mathrm{PbI}_{2}$ with different nanocrystals and different morphologies, such as nanorods [7], nanotubes [8], nanowires [9], nanosheets [10], nanoplatelets [11], hollow spheres [12], nanospheres [13] by chemical and physical methods, including liquid crystal template [7], self-assembled growth [8], vapor-liquid-solid process (VLS) [9], solvothermal synthesis [10,11], argon transport method [11], hydrothermal method [13]. To the best of our knowledge, there have not been any reports on the synthesis of $\mathrm{PbI}_{2}$ fibers.

Perovskite is a common metallo-organic compound crystal, which is composed mainly of calcium titanium oxide $\left(\mathrm{CaTiO}_{3}\right)$. It generally refers to a compound similar to the crystal structure of $\mathrm{CaTiO}_{3}$, with generic chemical formula $\mathrm{ABX}_{3}$. Organic-inorganic hybrid perovskite materials which meant including inorganic atoms and organic molecular clusters have been extensively investigated due to their excellent optical, electrical and mechanical properties [14]. Recently, methylammonium lead halide perovskites, $\mathrm{CH}_{3} \mathrm{NH}_{3} \mathrm{PbX}_{3}(\mathrm{X}=\mathrm{Cl}, \mathrm{Br}$, I), have demonstrated impressive progress as a new category of semiconductor light absorbers leading to solar cells with over $20.1 \%$ solar conversion efficiencies [15,16]. The $\mathrm{CH}_{3} \mathrm{NH}_{3} \mathrm{PbI}_{3}\left(\mathrm{MAPbI}_{3}\right)$ perovskite semiconductor has attracted attention because of the ease of solution processing and excellent absorption properties. It was often formed from the solution, such as $\gamma$-butyrolactone [17] and $N, N$-dimethylformamide (DMF) [18], containing equimolar mixture of methylammonium iodide $\left(\mathrm{CH}_{3} \mathrm{NH}_{3} \mathrm{I}, \mathrm{MAI}\right)$ and $\mathrm{PbI}_{2}$ by coprecipitation method using spin coating technique. In addition, Chen et al. reported a one-pot solvothermal approach to synthesize the cuboid shaped $\mathrm{MAPbI}_{3}$ single crystals [19]. However, in our study, one-dimensional $\mathrm{PbI}_{2} / \mathrm{PVP}$ composite fibers have been prepared via an electrospinning process and then immersed in MAI solution to form perovskite $\mathrm{MAPbI}_{3} / \mathrm{PVP}$ composite fibers. The preparation method was similar to that which is used to prepare PAN/ZnS composite nanofibers [20].

\section{Results and Discussion}

\section{1. $\mathrm{PbI}_{2} / \mathrm{PVP}$ Composite Fibers}

An X-ray powder diffraction (XRD) analysis is conducted on $\mathrm{PbI}_{2} / \mathrm{PVP}$ composite fibers produced by electro spinning, with the results shown in Figure 1. The indicated peak complies with the multiple 
crystalline phases of $\mathrm{PbI}_{2}$ (JCPDs No. 80-1000). It was found that $\mathrm{PbI}_{2}$ powder forms a composite fiber with PVP after dissolution and electrospinning. Without a high-temperature and high-voltage process, $\mathrm{PbI}_{2}$ undergoes phase changes, so that its structure does not change.

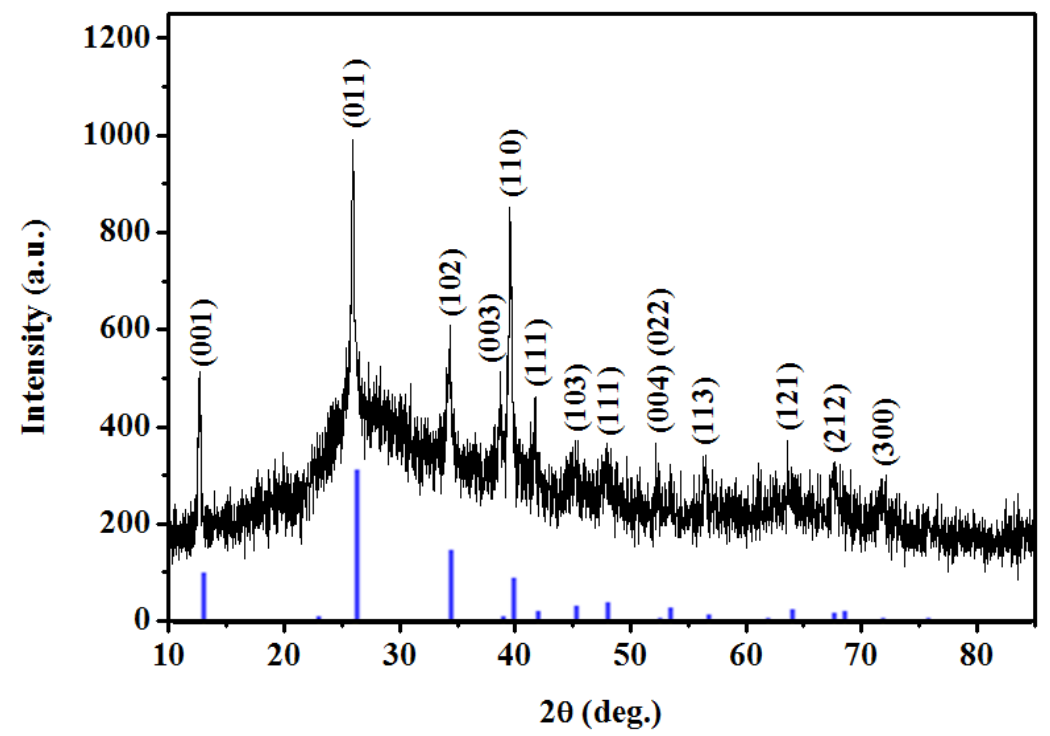

Figure 1. XRD diagram of $\mathrm{PbI}_{2} /$ polyvinylpyrrolidone (PVP) composite fibers obtained from the electrospinning experiment using a precursor solution of $4.55 \mathrm{wt} \%$ PVP with $16 \mathrm{kV}$ applied voltage, $10 \mathrm{~cm}$ spinning distance and flow rate of $1 \mathrm{~mL} / \mathrm{h}$. The Blue peaks are from JCPDs No. 80-1000 of $\mathrm{PbI}_{2}$.

The working parameters of electrospinning included solution parameters, process parameters and ambient parameters, which did not only influence the electrospinning process, but also affected the transformation of polymeric precursor solutions into fibers. The synthesis experiment of $\mathrm{PbI}_{2} / \mathrm{PVP}$ composite fibers explored the changing polymer concentration (C) among solution parameters, applied voltage (V) of process parameters, spinning distance (L), and flow rate (FR).

The polymer concentrations of precursor solution play an important role in the fiber formation during the electrospinning process [2]. The morphology and size of electrospun nanofibers depend on solution properties such as viscosity. Concentration is a primary factor determining the solution viscosity [4]. We used the precursor solutions with 3.08-5.03 wt\% PVP, $15 \mathrm{kV}$ applied voltage, $10 \mathrm{~cm}$ spinning distance and flow rate of $1.0 \mathrm{~mL} / \mathrm{h}$ during the electrospinning process to synthesize fibers, and we observed the effect of polymer concentration on fibers. The viscosity of the $\mathrm{PbI}_{2} / \mathrm{PVP}$ precursor solutions was about 82.5 to $100 \mathrm{cPs}$ (Figure 2). The diameter of the output fibers is about $110-400 \mathrm{~nm}$ and the apperance is smooth without beads (Figure 3). And, the average diameter and the viscosity of the precursor solutions under higher PVP concentration tends to increase (Figure 4a). This is in agreement with Chen et al. [21], who mentioned in the electrospinning experiment on PVP fiber production that, with the increase of polymer PVP concentration in the precursor solution, the solution viscosity would become higher, making the fiber surface smooth without beads. This would also be helpful to the output of the fibers given the corresponding increase in average diameters [22]. However, the average diameter of the fibers produced from the precursor solution with $4.55 \mathrm{wt} \%$ PVP was small and uniform. It was 
also the smallest among the mean fiber diameters, which surpassed our expectation. As for the fibers produced from $3.08 \mathrm{wt} \%$ PVP, the fiber films could be easily obtained from the collection board in large pieces and clots. Thus, in succeeding steps, the precursor solutions with $4.55 \mathrm{wt} \%$ PVP were used.

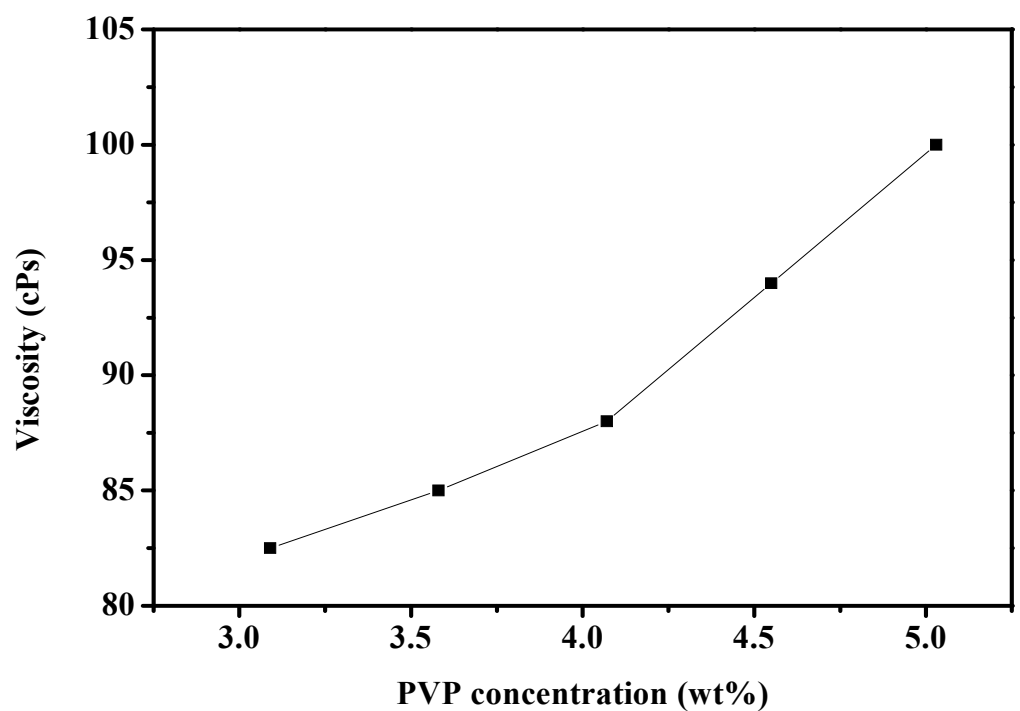

Figure 2. The changes in viscosity of $\mathrm{PbI}_{2} / \mathrm{PVP}$ precursor solutions with its concentration.

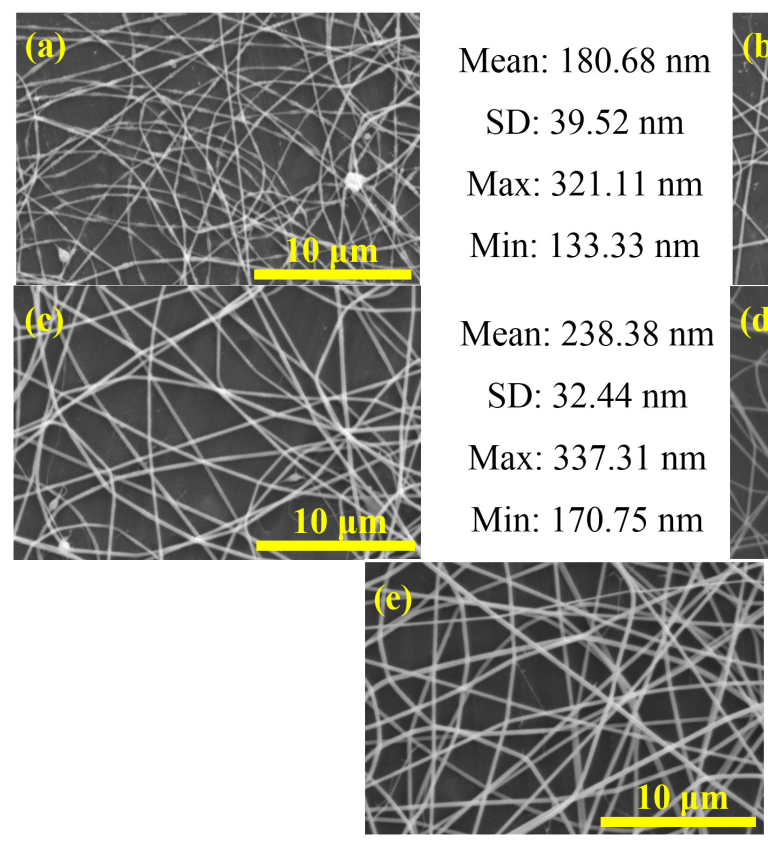

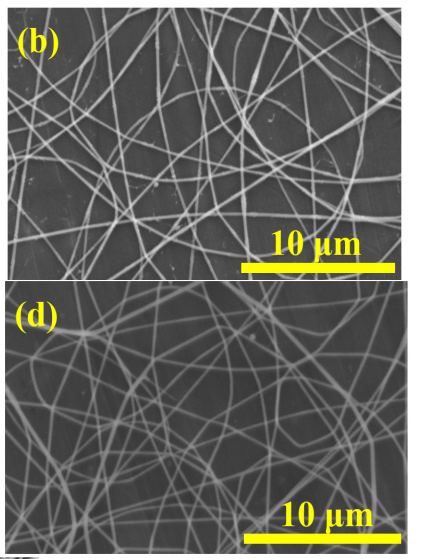

Mean: $212.86 \mathrm{~nm}$

SD: $37.27 \mathrm{~nm}$

Max: $340.59 \mathrm{~nm}$

Min: $140.00 \mathrm{~nm}$

Mean: $195.50 \mathrm{~nm}$

SD: $34.61 \mathrm{~nm}$

Max: $298.14 \mathrm{~nm}$

Min: $119.26 \mathrm{~nm}$

Mean: $270.18 \mathrm{~nm}$

SD: $39.46 \mathrm{~nm}$

Max: $393.73 \mathrm{~nm}$

Min: $162.21 \mathrm{~nm}$

Figure 3. Scanning electron microscopy (SEM) images of $\mathrm{PbI}_{2} / \mathrm{PVP}$ composite fibers produced from precursor solutions with different PVP concentration: (a) 3.08; (b) 3.58; (c) 4.07; (d) 4.55 and (e) $5.03 \mathrm{wt} \%(\mathrm{~V}=15 \mathrm{kV}, \mathrm{L}=10 \mathrm{~cm}, \mathrm{FR}=1.0 \mathrm{~mL} / \mathrm{h})$. The figure also shows the mean, standard deviation (SD), maximum and minimum values of the fiber diameter. 


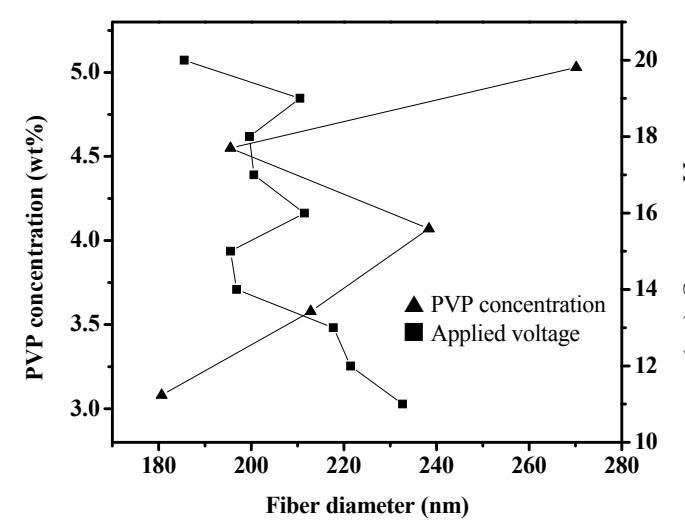

(a)

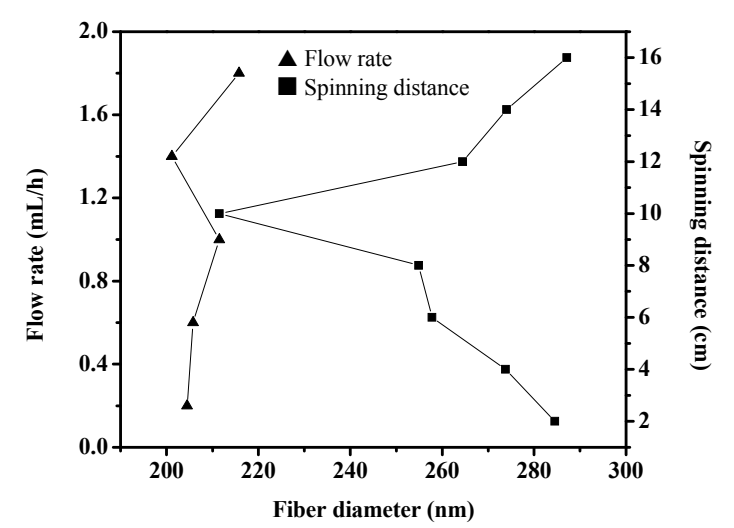

(b)

Figure 4. The average diameter tendency chart of $\mathrm{PbI}_{2} / \mathrm{PVP}$ composite fibers produced by changing the working parameters of electrospinning: (a) PVP concentration and applied voltage; (b) spinning distance and flow rate.

The applied voltage is a critical factor in electrospinning. When the applied voltage is higher than the threshold voltage, charged jets could be ejected from Taylor Cone [2]. In the electrospinning experiment published by $\mathrm{Li}$ and $\mathrm{Xia}$ [23], it was found that when applied voltage increases, the fiber diameter would be smaller. However, when voltage is higher than a certain value, the fiber diameter would be larger. Most studies supported these findings, but the applied voltage does not significantly influence the fiber diameter [22]. In order to observe whether applied voltage has significant influence on the formation of $\mathrm{PbI}_{2} / \mathrm{PVP}$ composite fibers, we designed different applied voltages with a fixed spinning distance of $10 \mathrm{~cm}$ and flow rate of $1.0 \mathrm{~mL} / \mathrm{h}$ for fiber output during electrospinning. The diameter of the fiber with smooth apperance is about 130-390 nm (Figure 5). Based on Figure 4a, with an increase in applied voltage, the average fiber diameter tends to be smaller even though it does not show obvious and regular changes.

In the electrospinning experiment of Lee et al., it was found that changing the spinning distance between the needle tip and the collection board could obtain fibers with smaller diameters [24]. When the spinning distance is too short, the fiber would not have enough time to solidify. However, if it is too long, it would generate fibers with beads [2]. In this experiment, we used different spinning distances, applied voltage of $16 \mathrm{kV}$ and flow rate of $1.0 \mathrm{~mL} / \mathrm{h}$ to produce fiber. In the trend chart shown in Figure $4 \mathrm{~b}$ and the SME diagram in Figure 6, the fiber diameter is between 150 and $530 \mathrm{~nm}$. When the spinning distance continues to grow longer, the beads become less and less until they finally disappear. However, the fiber diameter becomes smaller first and gradually gets bigger.

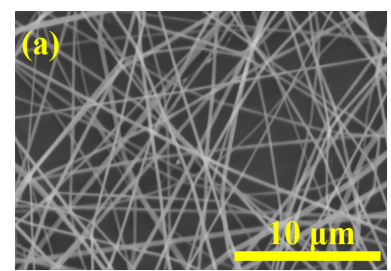

Mean: $221.47 \mathrm{~nm}$

SD: $47.75 \mathrm{~nm}$

Max: $388.27 \mathrm{~nm}$

Min: $133.33 \mathrm{~nm}$

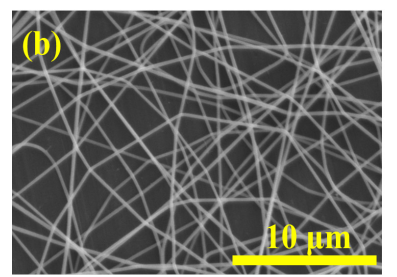

Mean: $196.84 \mathrm{~nm}$

SD: $30.86 \mathrm{~nm}$

Max: $274.55 \mathrm{~nm}$

Min: $143.60 \mathrm{~nm}$

Figure 5. Cont. 


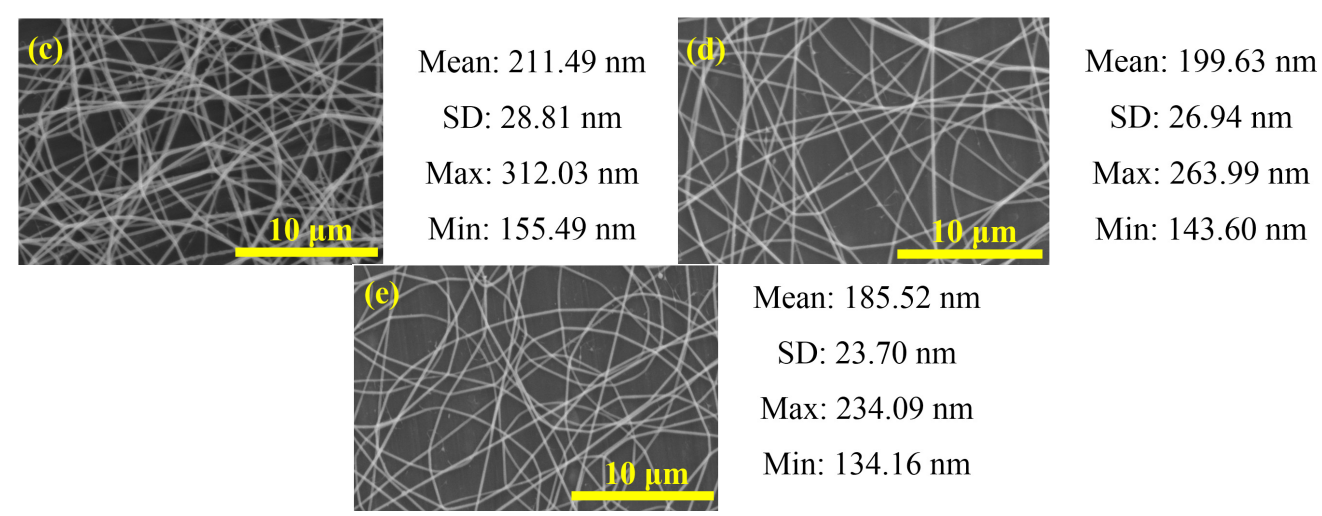

Figure 5. SEM images of $\mathrm{PbI}_{2} / \mathrm{PVP}$ composite fibers produced at different applied voltages:

(a) 12; (b) 14; (c) 16; (d) 18 and (e) $20 \mathrm{kV}(\mathrm{L}=10 \mathrm{~cm}, \mathrm{FR}=1.0 \mathrm{~mL} / \mathrm{h})$.

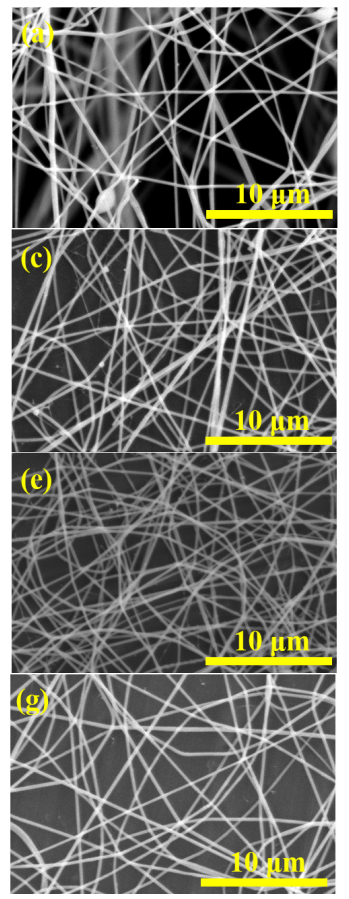

Mean: $284.49 \mathrm{~nm}$
SD: $76.28 \mathrm{~nm}$
Max: $528.39 \mathrm{~nm}$
Min: $161.25 \mathrm{~nm}$
Mean: $257.78 \mathrm{~nm}$
SD: $35.42 \mathrm{~nm}$
Max: $367.15 \mathrm{~nm}$
Min: $205.91 \mathrm{~nm}$
Mean: $211.49 \mathrm{~nm}$
SD: $28.81 \mathrm{~nm}$
Max: $312.03 \mathrm{~nm}$
Min: $155.49 \mathrm{~nm}$
Mean: $274.03 \mathrm{~nm}$
SD: $37.64 \mathrm{~nm}$
Max: $394.46 \mathrm{~nm}$
Min: $197.99 \mathrm{~nm}$

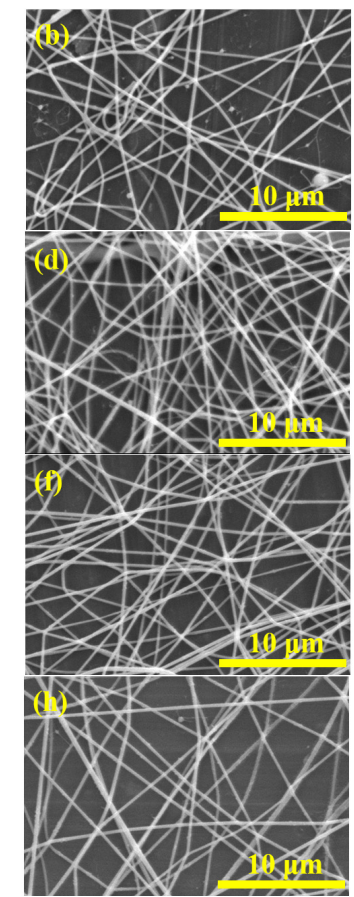

Mean: $273.78 \mathrm{~nm}$ SD: $32.05 \mathrm{~nm}$ Max: $394.46 \mathrm{~nm}$ Min: $197.99 \mathrm{~nm}$ Mean: $254.89 \mathrm{~nm}$ SD: $40.01 \mathrm{~nm}$ Max: $394.46 \mathrm{~nm}$ Min: $184.39 \mathrm{~nm}$ Mean: $264.45 \mathrm{~nm}$ SD: $38.38 \mathrm{~nm}$ Max: $360.00 \mathrm{~nm}$ Min: $181.11 \mathrm{~nm}$ Mean: $287.14 \mathrm{~nm}$ SD: $45.44 \mathrm{~nm}$ Max: $432.67 \mathrm{~nm}$ Min: $212.60 \mathrm{~nm}$

Figure 6. $\mathrm{SEM}$ images of $\mathrm{PbI}_{2} / \mathrm{PVP}$ composite fibers produced at different spinning distance: (a) 2; (b) 4; (c) 6; (d) 8; (e) 10; (f) 12; (g) 14 and (h) $16 \mathrm{~cm}(\mathrm{~V}=16 \mathrm{kV}, \mathrm{FR}=1.0 \mathrm{~mL} / \mathrm{h})$.

The flow rate of the precursor solution is a key process parameter in electrospinning, which leaves enough time for the precursor solution to polarize [2]. However, it does not have absolute influence on the size of the fiber diameter. Based on the findings of Li et al. [23] and Megelski et al. [25], when flow rate is increased, the fiber diameter becomes larger. However, according to the experimental results of Tan et al. [22], there are no significant changes. This experiment observed the influence of flow rate from fiber produced at different flow rates, $16 \mathrm{kV}$ applied voltage and $10 \mathrm{~cm}$ spinning distance. The fiber diameter is about 140-390 nm with a smooth apperance, but the beads are gradually produced under high flow rate (Figure 7). Based on Figure $4 b$, the fiber diameter shows no significant change under higher flow rate. 


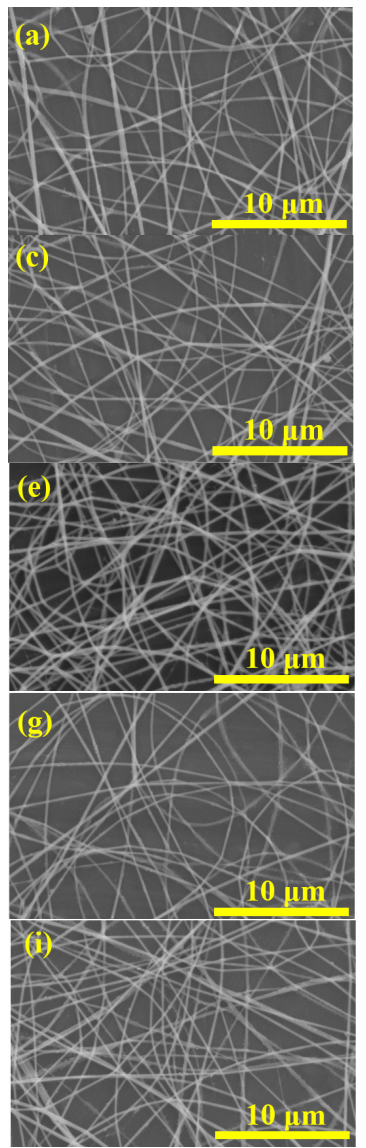

Mean: $204.47 \mathrm{~nm}$ SD: $44.92 \mathrm{~nm}$ Max: $329.85 \mathrm{~nm}$ Min: $145.60 \mathrm{~nm}$ Mean: $205.79 \mathrm{~nm}$ SD: $39.51 \mathrm{~nm}$ Max: $335.26 \mathrm{~nm}$ Min: 141.42 nm

Mean: $211.49 \mathrm{~nm}$ SD: $28.81 \mathrm{~nm}$ Max: $312.03 \mathrm{~nm}$ Min: $155.49 \mathrm{~nm}$ Mean: $201.15 \mathrm{~nm}$ SD: $34.10 \mathrm{~nm}$ Max: $272.03 \mathrm{~nm}$ Min: $140.00 \mathrm{~nm}$ Mean: $215.79 \mathrm{~nm}$ SD: $40.65 \mathrm{~nm}$ Max: $322.49 \mathrm{~nm}$ Min: $145.60 \mathrm{~nm}$

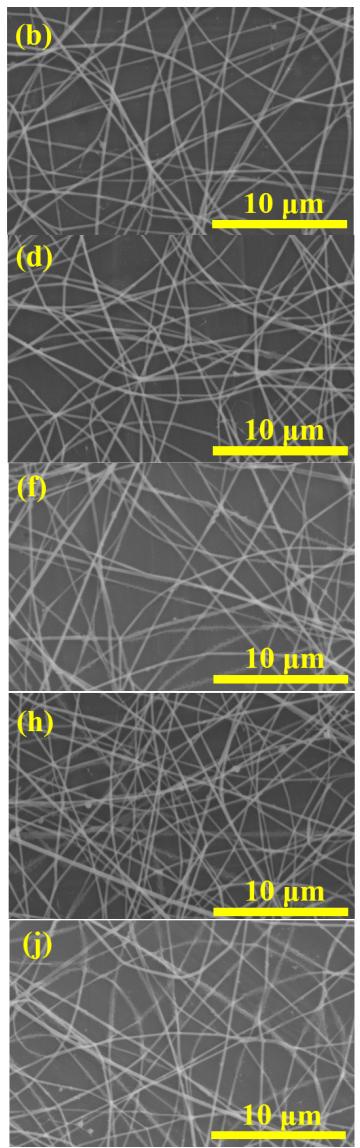

Mean: $199.14 \mathrm{~nm}$ SD: $24.43 \mathrm{~nm}$ Max: $263.06 \mathrm{~nm}$ Min: $141.42 \mathrm{~nm}$ Mean: $197.73 \mathrm{~nm}$ SD: $26.16 \mathrm{~nm}$ Max: $277.85 \mathrm{~nm}$ Min: $141.42 \mathrm{~nm}$ Mean: $206.51 \mathrm{~nm}$ SD: $41.43 \mathrm{~nm}$ Max: $384.71 \mathrm{~nm}$ Min: $128.06 \mathrm{~nm}$ Mean: $206.59 \mathrm{~nm}$ SD: $36.73 \mathrm{~nm}$ Max: $320.00 \mathrm{~nm}$ Min: $152.32 \mathrm{~nm}$ Mean: $200.20 \mathrm{~nm}$ SD: $43.33 \mathrm{~nm}$ Max: $332.87 \mathrm{~nm}$ Min: $140.00 \mathrm{~nm}$

Figure 7. $\mathrm{SEM}$ images of $\mathrm{PbI}_{2} / \mathrm{PVP}$ composite fibers produced at different flow rate: (a) 0.2 ; (b) 0.4 ; (c) 0.6 ; (d) $0.8 ;$ (e) 1.0 ; (f) $1.2 ;$ (g) 1.4 ; (h) 1.6 ; (i) 1.8 and (j) $2.0 \mathrm{~mL} / \mathrm{h}(\mathrm{V}=16 \mathrm{kV}$, $\mathrm{L}=1.0 \mathrm{~cm})$.

To sum up the above experiments for each parameter, we can deduce that $\mathrm{PbI}_{2} / \mathrm{PVP}$ composite fibers produced under an applied voltage of $16 \mathrm{kV}$, spinning distance of $10 \mathrm{~cm}$ and flow rate of $1.0 \mathrm{~mL} / \mathrm{h}$, have small and uniform average fiber diameter (with small standard deviation), and smooth surface without beads. Thus, such fibers are used as base material to synthesize $\mathrm{MAPbI}_{3} / \mathrm{PVP}$ composite fiber.

\section{2. $\mathrm{MAPbI}_{3} / \mathrm{PVP}$ Composite Fibers}

$\mathrm{PbI}_{2} / \mathrm{PVP}$ composite fibers were immersed in $0.1 \mathrm{M}$ or $0.2 \mathrm{M}$ MAI solution for 3-20 min, and rinsed with IPA for $5 \mathrm{~s}$ or $5 \mathrm{~min}$ to form $\mathrm{MAPbI}_{3} / \mathrm{PVP}$ composite fibers. Afterwards, an XRD test was conducted to obtain the results shown in Figure 8. JCPDs No. 80-1000 was used for $\mathrm{PbI}_{2}$ while [26] was used for $\mathrm{MAPbI}_{3}$ as reference for comparison. It was observed that the fibers generated $\mathrm{MAPbI}_{3}$ which was still mixed with $\mathrm{PbI}_{2}$. This was probably because of the $\mathrm{PbI}_{2}$ scattered in the PVP polymer fiber which did not react with MAI. As for the fiber appearance, the SME diagram (Figure 9) shows square particles generated on the fibers. A longer immersion time would generate larger particles and large fiber diameters in molten state. However, it was found that fibers produced when immersed in $0.1 \mathrm{M} \mathrm{MAI/IPA}$ solution for $10 \mathrm{~min}$ and rinsed with IPA for $5 \mathrm{~s}$, were clearly visible and uniform in size (Figure 9c), which had less square particles than fibers immersed for $5 \mathrm{~min}$ and $20 \mathrm{~min}$. 


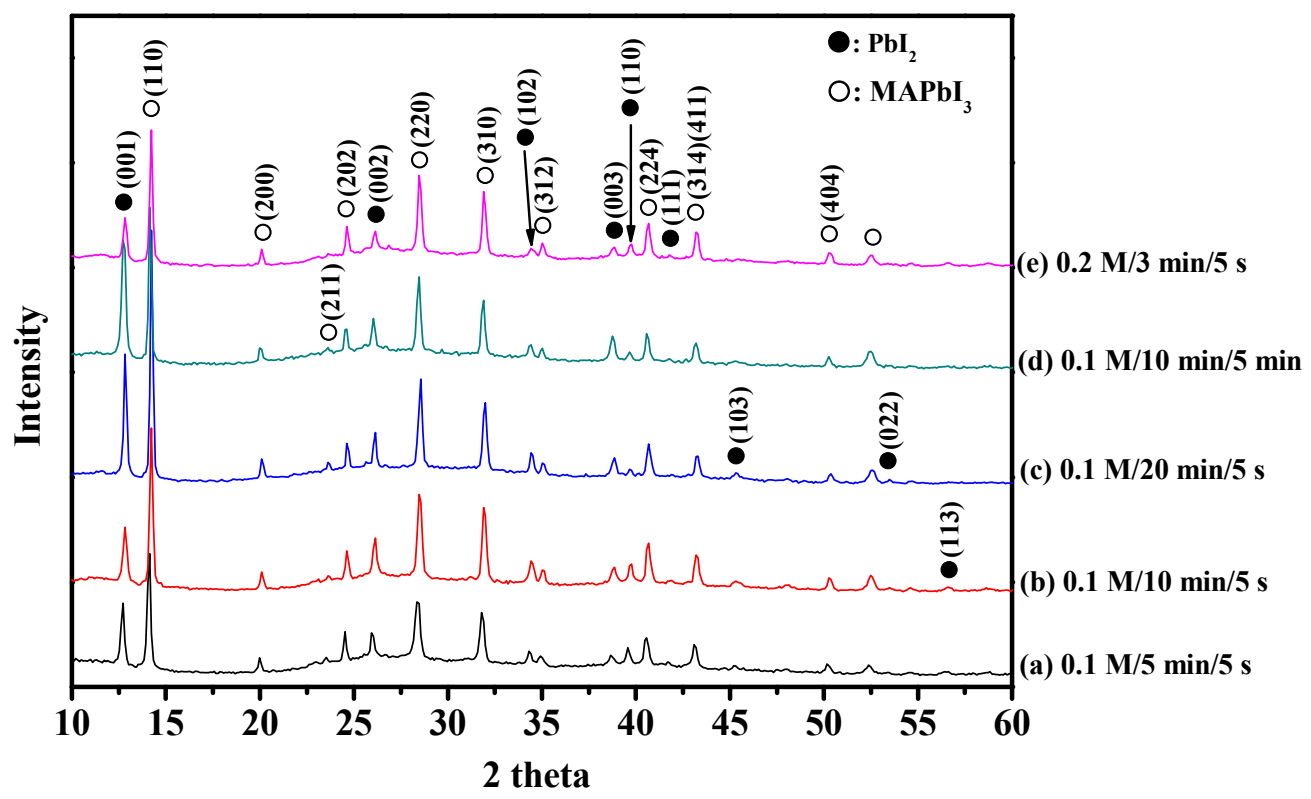

Figure 8. $\mathrm{XRD}$ images of $\mathrm{MAPbI}_{3} / \mathrm{PVP}$ composite fibers produced at different MAI/IPAconcertaion/immersing time/IPA rinsing time.

Although this experiment outputs perovskite $\mathrm{MAPbI}_{3}$ fibers, it could hinder the function of electrons when applied in the production of perovskite battery components due to the existence of $\mathrm{PbI}_{2}$ and $\mathrm{PVP}$. Thus, it is important to correct the formation of $\mathrm{MAPbI}_{3}$ fibers. In addition, Znao and Zhu investigated the impact of $\mathrm{a} \mathrm{NH}_{3}$ gas environment on the structural and optical properties of $\mathrm{MAPbI}_{3}$ [15]. Therefore, we will try to show that the $\mathrm{MAPbI}_{3} / \mathrm{PVP}$ composite fibers can potentially be used as ammonia sensors with both a fast response time and a wide range of spectral responses in the future.

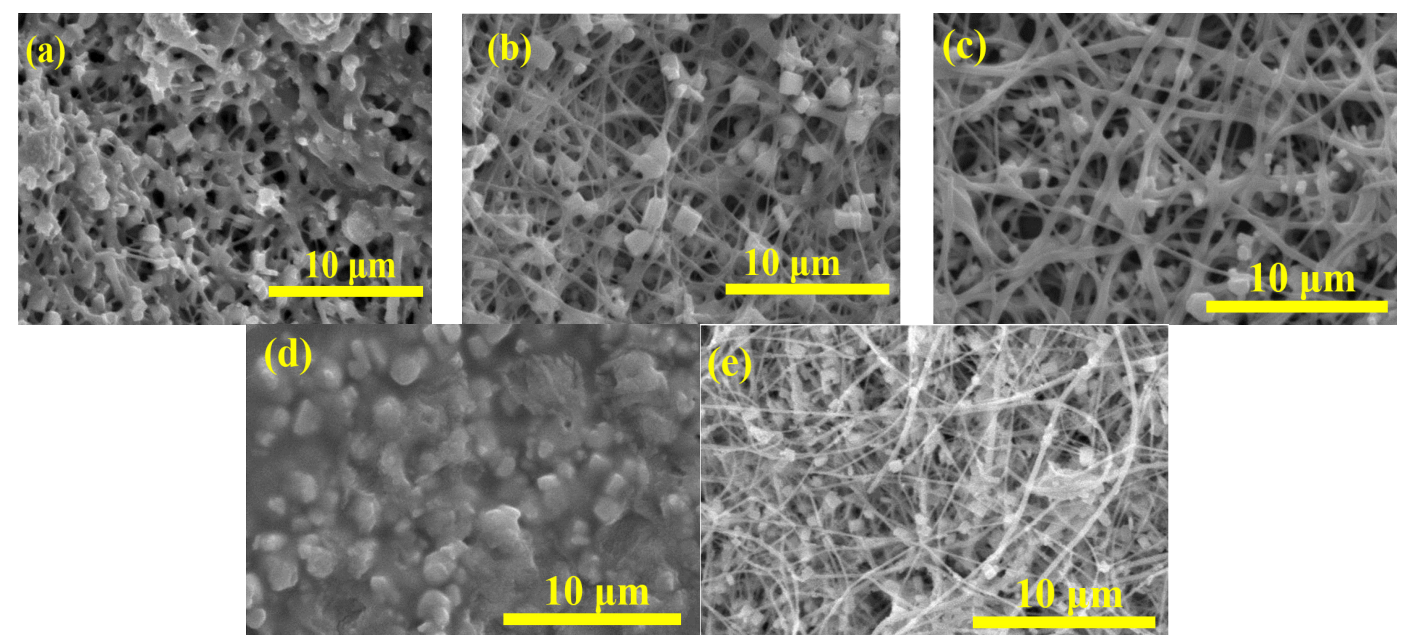

Figure 9. SEM images of $\mathrm{MAPbI}_{3} / \mathrm{PVP}$ composite fibers produced at different MAI/IPA different $\mathrm{MAI} /$ isopropyl alcohol (IPA) concertaion/immersing time/IPA rinsing time: (a) $0.1 \mathrm{M} / 5 \mathrm{~min} / 5 \mathrm{~s}$; (b) $0.1 \mathrm{M} / 10 \mathrm{~min} / 5 \mathrm{~s}$; (c) $0.1 \mathrm{M} / 10 \mathrm{~min} / 5 \mathrm{~min}$; (d) $0.1 \mathrm{M} / 20 \mathrm{~min} / 5 \mathrm{~s}$ and (e) $0.2 \mathrm{M} / 3 \mathrm{~min} / 5 \mathrm{~s}$. 


\section{Experimental Section}

\subsection{Materials}

PVP (average $M_{w}=1,300,000$, Acros Organics, Morris Plains, NJ, USA), $\mathrm{PbI}_{2}$ (100\%, Showa Chemical, Tokyo, Japan), DMF (99.9\%, Fisher Scientific, Fair Lawn, NJ, USA), methylamine (40 wt\% in methanol, Panreac Sintesis, Barcelona, Spain), hydroiodic acid (57 wt\% in water, Showa Chemical, Tokyo, Japan), isopropyl alcohol (IPA, 99.9+\%, Burdick \& Jackson, Ulsan, Korea), diethyl ether (99\%, Echo Chemical, MiaoLi, Taiwan) were used as received, without further purification.

\subsection{Synthesis of $\mathrm{PbI}_{2} / \mathrm{PVP}$ Composite Fibers}

Exactly $2.71 \mathrm{mmol}(1.248 \mathrm{~g})$ of $\mathrm{PbI}_{2}$ was stirred to dissolve in $3 \mathrm{~mL}$ of DMF by magnetic force at $70{ }^{\circ} \mathrm{C}$, and then $0.18,0.21,0.24,0.27,0.30 \mathrm{~g}$ PVP in $3 \mathrm{~mL}$ of DMF was tardily dropped into it at room temperature. The homogeneous $\mathrm{PbI}_{2} / \mathrm{PVP}$ composites precursor solutions with 3.08, 3.58, 4.07, 4.55, $5.03 \mathrm{wt} \%$ PVP were obtained.

Take $10 \mathrm{~mL}$ of the precursor solution into a 26-gauge syringe (with $0.82 \mathrm{~mm}$ diameter), which is fixed on a spring pump. The flow rate of the liquid is $0.2,0.4,0.6,0.8,1.0,1.2,1.4,1.6,1.8,2.0 \mathrm{~mL} / \mathrm{h}$. A high-voltage power supply is connected to the needle tip from one end and to the collection board on the other end. The applied voltage is $11,12,13,14,15,16,17,18,19,20 \mathrm{kV}$. The needle tip-to-collector distance is the spinning distance, which is $2,4,6,8,10,12,14,16 \mathrm{~cm}$. Since high voltage was applied, a drop of the precursor solution on the tip of the syringe would become polarized. In a high voltage electric field, the initial semi-circle drops form a Taylor cone. After the repulsive force between the electric charges becomes larger than the tensile force on the surface, the bottom of the Taylor cone would eject the charged jets. In the electric field, the jets usually pass by in a nearly straight line after bending into a complex path. When the jets are in the air, the volatile solution undergoes volatilization. Finally, the fiber films with a diameter at the nanometer level can be obtained on the collection board [2]. By drying the collected fibers at $80{ }^{\circ} \mathrm{C}$, various kinds of $\mathrm{PbI}_{2} / \mathrm{PVP}$ composite fibers in different sizes can be obtained. The electrospinning setup used in this work is shown in Figure 10.

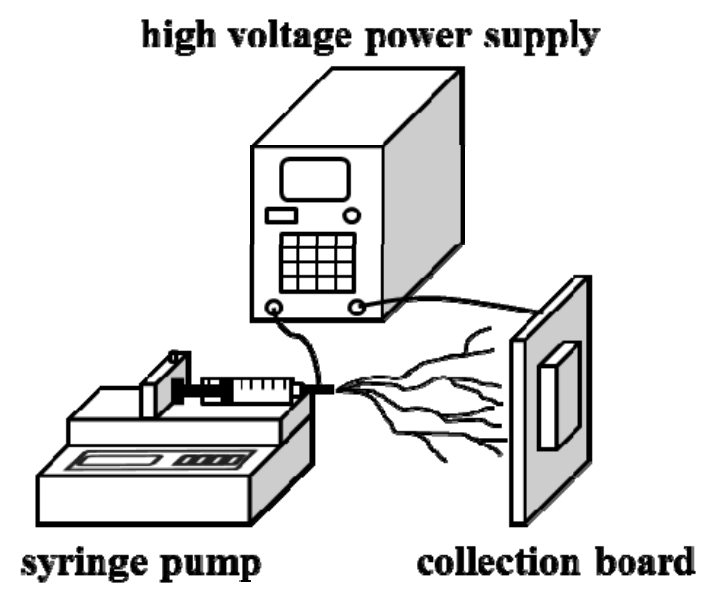

Figure 10. Electrispining device diagram. 


\subsection{Synthesis of $\mathrm{CH}_{3} \mathrm{NH}_{3} \mathrm{PbI}_{3} / \mathrm{PVP}$ Composite Fibers}

The MAI powder compounded based on the literature [17] is dissolved into the IPA blending solution with a concentration of $0.1,0.2 \mathrm{M}$. The $\mathrm{PbI}_{2} / \mathrm{PVP}$ composite fibers are immersed into the blending solution for some time before taken out. The color of the fiber would be black, indicating that $\mathrm{MAPbI}_{3}$ is generated on the fiber. The fiber is then rinsed with IPA solution and dried at a temperature below $70{ }^{\circ} \mathrm{C}$ before finally obtaining $\mathrm{MAPbI}_{3} / \mathrm{PVP}$ composite fibers.

\subsection{Characterization}

The XRD patterns of the as-prepared samples were measured using a Rigaku MiniFlex II X-ray diffractometer (Tokyo, Japan) $(\theta / 2 \theta$ geometry, $\mathrm{Cu} \mathrm{K} \alpha$ radiation of $\lambda=0.15418 \mathrm{~nm}$, graphite monochromator, scintillation counter, operating at $30 \mathrm{kV} \times 15 \mathrm{~mA}$, step width $0.02^{\circ}$, scan rate of $4^{\circ} / \mathrm{min}$, measured range of $10^{\circ}$ to $85^{\circ}$ in $2 \theta$ ). The morphology of all composite fibers was observed using Hitachi S-3000N SEM (Tokyo, Japan) (operating at $15 \mathrm{kV}$ ).

\section{Conclusions}

In this work, $\mathrm{PbI}_{2} / \mathrm{PVP}$ composite fibers were successfully fabricated via electrospinning. We made the most suitable $\mathrm{PbI}_{2} / \mathrm{PVP}$ composite fibers with the fiber diameter about 140-390 nm under $4.55 \mathrm{wt} \%$ PVP concentration, $16 \mathrm{kV}$ applied voltage, $10 \mathrm{~cm}$ spinning distance, and $1.0 \mathrm{~mL} / \mathrm{h}$ flow rate of working parameters on electrospinning. After the most suitable $\mathrm{PbI}_{2} / \mathrm{PVP}$ composite fibers were dipped into $0.1 \mathrm{M} \mathrm{MAI} / \mathrm{IPA}$ solution for $10 \mathrm{~min}$, the better $\mathrm{MAPbI}_{3} / \mathrm{PVP}$ composite fibers could be obtained. Despite the $\mathrm{MAPbI}_{3} / \mathrm{PVP}$ composite fibers was not used as the sensitizer of solar cells, they will be able to as ammonia sensors.

\section{Acknowledgments}

The authors thank the Ministry of Science and Technology of Taiwan for financial support, under grant no. MOST 103-2113-M-024-001.

\section{Author Contributions}

All authors contributed to this work, discussed the results and implications and commented on the manuscript at all stages. Pei-Ying Lin and Yaw-Shyan Fu conceived the strategies. Yaw-Shyan Fu supervised the project. Ting-Yu Tai, Yueh-Ying Chen and Pei-Ying Lin designed and performed experiments, analyzed data. Li-Min Chao wrote the paper.

\section{Conflicts of Interest}

The authors declare no conflict of interest. 


\section{References}

1. Schadler, L.S. Polymer-Based and Polymer-Filled Nanocomposites. In Nanocomposite Science and Technology; Ajayan, P.M., Schadler, L.S., Braun, P.V., Eds.; Wiley-VCH Verlag GmbH \& Co. KGaA: Weinheim, Germany, 2003; pp. 77-153.

2. Li, Z.; Wang, C. One-Dimensional Nanostructures; Springer: Berlin, Germany; Heidelberg, Germany, 2013.

3. Greiner, A.; Wendorff, J.H. Electrospinning: A fascinating method for the preparation of ultrathin fibers. Angew. Chem. Int. Ed. 2007, 46, 5670-5703. [CrossRef] [PubMed]

4. Yang, Q.; Li, Z.; Hong, Y.; Zhao, Y.; Qiu, S.; Wang, C.; Wei, Y. Influence of solvents on the formation of ultrathin uniform poly(vinyl pyrrolidone) nanofibers with electrospinning. J. Polym. Sci. Pol. Phys. 2004, 42, 3721-3726. [CrossRef]

5. Schlüter, I.C.; Schlüter, M. Electronic structure and optical properties of $\mathrm{PbI}_{2}$. Phys. Rev. B 1974, 9, 1652-1663. [CrossRef]

6. Zhu, G.; Hojamberdiev, M.; Liua, P.; Peng, J.; Zhou, J.; Bian, X.; Huang, X. The effects of synthesis parameters on the formation of $\mathrm{PbI}_{2}$ particles under DTAB-assisted hydrothermal process. Mater. Chem. Phys. 2011, 131, 64-71. [CrossRef]

7. Artemyev, M.V.; Rakovich, Y.P.; Yablonski, G.P. Effect of dc electric field on photoluminescence from quantum-confined $\mathrm{PbI}_{2}$ nanocrystals. J. Cryst. Growth 1997, 171, 447-452. [CrossRef]

8. Chang, Y.C.; James, R.B. Phonon dispersion and polar-optical scattering in $2 \mathrm{H} \mathrm{PbI}_{2}$. Phys. Rev. B 1997, 55, 8219-8225. [CrossRef]

9. Schlesinger, T.E.; James, R.B.; Schieber, M.; Toney, J.; Scyoc, J.M.V.; Salary, L.; Hermon, H.; Lund, J.; Burger, A.; Chen, K.T.; et al. Characterization of lead iodide for nuclear spectrometers. Nucl. Instrum. Methods Phys. Res. Sect. A Accel. Spectrom. Dect. Assoc. Equip. 1996, 380, 193-197. [CrossRef]

10. George, M.A.; Azoulay, M.; Jayatirtha, H.N.; Biao, Y.; Burger, A.; Collins, W.E.; Silberman, E. Atomic force microscopy of lead iodide crystal surfaces. J. Cryst. Growth 1994, 137, 299-303. [CrossRef]

11. Sandroff, C.J.; Hwang, D.M.; Chung, W.M. Carrier confinement and special crystallite dimensions in layered semiconductor colloids. Phys. Rev. B 1986, 33, 5953-5955. [CrossRef]

12. Sengupta, A.; Jiang, B.; Mandal, K.C.; Zhang, J.Z. Ultrafast electronic relaxation dynamics in $\mathrm{PbI}_{2}$ semiconductor colloidal nanoparticles: A femtosecond transient absorption study. J. Phys. Chem. B 1999, 103, 3128-3137. [CrossRef]

13. Mu, R.; Tung, Y.S.; Ueda, A.; Henderson, D.O. Chemical and size characterization of layered lead iodide quantum dots via optical spectroscopy and atomic force microscopy. J. Phys. Chem. 1996, 100, 19927-19932. [CrossRef]

14. Gao, P.; Grätze, M.; Nazeeruddin, M.K. Organohalide lead perovskites for photovoltaic applications. Energy Environ. Sci. 2014, 7, 2448-2463. [CrossRef]

15. Zhao, Y.; Zhu, K. Optical bleaching of perovskite $\left(\mathrm{CH}_{3} \mathrm{NH}_{3}\right) \mathrm{PbI}_{3}$ through room-temperature phase transformation induced by ammonia. Chem. Commun. 2014, 50, 1605-1607. [CrossRef] [PubMed] 
16. Zheng, L.; Zhang, D.; Ma, Y.; Lu, Z.; Chen, Z.; Wang, S.; Xiao, L.; Gong, Q. Morphology control of the perovskite films for efficient solar cells. Dalton Trans. 2015, 44, 10582-10593. [CrossRef] [PubMed]

17. Kim, H.-S.; Lee, C.-R.; Im, J.-H.; Lee, K.-B.; Moehl, T.; Marchioro, A.; Moon, S.-J.; Humphry-Baker, R.; Yum, J.-H.; Moser, J.E.; et al. Lead iodide perovskite sensitized all-solid-state submicron thin film mesoscopic solar cell with efficiency exceeding 9\%. Sci. Rep. 2012, 2. [CrossRef] [PubMed]

18. Burschka, J.; Pellet, N.; Moon, S.J.; Humphry-Baker, R.; Gao, P.; Nazeeruddin, M.K.; Grätzel, M. Sequential deposition as a route to high-performance perovskite-sensitized solar cells. Nature 2013, 499, 316-319. [CrossRef] [PubMed]

19. Chen, Y.; Yang, S.; Chen, X.; Zheng, Y.C.; Hou, Y.; Li, Y.H.; Zeng, H.D.; Yang, H.G. Direct insight into crystallization and stability of hybrid perovskite $\mathrm{CH}_{3} \mathrm{NH}_{3} \mathrm{PbI}_{3}$ via solvothermal synthesis. J. Mater. Chem. A 2015, 3, 15854-15857. [CrossRef]

20. Ji, L.; Medford, A.J.; Zhang, X. Electrospun polyacrylonitrile/zinc chloride composite nanofibers and their response to hydrogen sulfide. Polymer 2009, 50, 605-612. [CrossRef]

21. Chen, M.; Qu, H.; Zhu, J.; Luo, Z.; Khasanov, A.; Kucknoor, A.S.; Haldolaarachchige, N.; Young, D.P.; Wei, S.; Guo, Z. Magnetic electrospun fluorescent polyvinylpyrrolidone nanocomposite fibers. Polymer 2012, 53, 4501-4511. [CrossRef]

22. Tan, S.H.; Inai, R.; Kotaki, M.; Ramakrishna, S. Systematic parameter study for ultra-fine fiber fabrication via electrospinning process. Polymer 2005, 46, 6128-6134. [CrossRef]

23. Li, D.; Xia, Y. Fabrication of titania nanofibers by electrospinning. Nano Lett. 2003, 3, 555-560. [CrossRef]

24. Lee, K.H.; Kim, H.Y.; La, Y.M.; Lee, D.R.; Sung, N. Influence of a mixing solvent with tetrahydrofuran and $N, N$-dimethylformamide on electrospun poly(vinyl chloride) nonwoven mats. J. Polym. Sci. Part B Polym. Phys. 2002, 40, 2259-2268. [CrossRef]

25. Megelski, S.; Stephens, J.S.; Chase, D.B.; Rabolt, J.F. Micro- and nanostructured surface morphology on electrospun polymer fibers. Macromolecules 2002, 35, 8456-8466. [CrossRef]

26. Sun, S.; Salim, T.; Mathews, N.; Duchamp, M.; Boothroyd, C.; Xing, G.; Sum, T.C.; Lam, Y.M. The origin of high efficiency in low-temperature solution-processable bilayer organometal halide hybrid solar cells. Energy Environ. Sci. 2014, 7, 399-407. [CrossRef]

(C) 2015 by the authors; licensee MDPI, Basel, Switzerland. This article is an open access article distributed under the terms and conditions of the Creative Commons Attribution license (http://creativecommons.org/licenses/by/4.0/). 